\title{
Innovative Activity Assessment of Industrial Enterprise: Methodological Approach
}

\author{
Serebryakova N.A.* \\ Voronezh State University of Engineering Technologies \\ Voronezh, Russia \\ e-mail: nad.serebryakova@mail.ru
}

Titova E.A.

Plekhanov Russian University of Economics

Voronezh branch, Russia

e-mail: e-titova1@yandex.ru

\section{Beliaeva G.V.}

Voronezh State University of Engineering Technologies

Voronezh, Russia

e-mail:bgv@vsuet.ru

\author{
Ponomareva N.I. \\ Voronezh State University of Engineering Technologies \\ Voronezh, Russia \\ e-mail: ponomareva220387@yandex.ru
}

\author{
Lukina O.O. \\ Voronezh State University of Engineering Technologies \\ Voronezh, Russia \\ e-mail: oks.lukina@gmail.com
}

\author{
Savvina E.A. \\ Voronezh State University of Engineering Technologies \\ Voronezh, Russia \\ e-mail: katenok2207@yandex.ru
}

deterioration of the production base, necessary to conduct research and development, lack of highly qualified personnel, difficulties in conducting market research in innovative sphere.

Due to structural and conceptual complexity of innovative process, it is necessary to search for effective forms and mechanisms to organize innovative activities at enterprises, as well as to develop new approaches for assessing industrial enterprise innovative activity development.

When the role of innovations for enterprise development is increasing, it is important to assess its efficiency by determining the magnitude of innovative impact and the degree of its influence on the performance of the enterprise structures and the state as a whole. Ensuring objective assessment of the state and direction of innovative activity development is crucial for making important managerial decisions.

Different methodological approaches to determine the criteria and a set of indicators are applied to assess the efficiency of innovative activities [3]. Methods used to manage innovative development of an industrial enterprise and a scientific organization are different, which leads to methodological discrepancies and difficulties when choosing the correct tool to conduct the assessment, that is at the moment there is no clearly established relationship between the results of scientific methodological developments and the practicality of their application in economic practice.

Successful functioning of industrial enterprises and their achievement of strategic advantages in competitive environment largely depends on their innovative activity development [2].

Thus, today industrial enterprises have to consider methodological issues when using different approaches for 
assessment and adjust them to regional specifics and then form methodological competences of managerial personnel [4].

\section{METHODS AND MATERIALS}

Nowadays, innovations are one of the most complex phenomena that determine economic growth, development and sustainability of financial and economic activities of any enterprise [1]. By innovation we understand an improved or new product (technological process), which has been realized as a result of innovative activity, which has a new, previously non-existent value for consumer and is sold on the market (having solvent demand), which creates competitive advantages and is used in practice. By innovation activity we understand activities related to the conduct of scientific research, development of new products, justification of discoveries, using their results in production, technological, organizational and administrative, financial, commercial, educational and other fields.

We can justify modern methodology for assessing industrial enterprise innovative activity development when we solve the following tasks:

- examine approaches to the concept "methodology";

- determine constituent elements for methodological apparatus of assessment;

- substantiate the need to apply selected approaches, methods, criteria, and indicators when conducting assessment within the framework of the proposed methodology.

The set of principles that contribute to the awareness of the laws of a particular scientific field, as well as research methods and their relationship, defines the category of "methodology".

We would like to stress, that it is advisable to assess development of innovative activity on the basis of methodology of modern economic science, using its tools.

The methodological apparatus of economic research is a system of methodological categories, which are the characteristics of economic research: the problem and its relevance, the object and subject of research, the goal and objectives, etc.

The methodological approach is not as formalized as the methodology, but it must take into account the following requirements:

- occurrence only in competitive environment, so a comparative approach must be applied;

- stability is mandatory, which requires all deviations from the equilibrium state to be considered;

- duration, which can be determined using dynamic indicators (chain or basic rate of change);

- research at the micro level, which considers an industrial enterprise an open economic system.

Almost all methods and methodological approaches for assessment of enterprise innovative activity development are based on the ratio of effect and cost, with their subsequent comparison to the standard value.

We propose a methodological approach for determining the integral effect a particular set of innovations can have on the key indicators of production and economic activity of an industrial enterprise over a certain period of time. In this regard, we can use the initial general approach, which is based on calculation (using a special algorithm) of the main indicators characterizing the economic efficiency of new technological and organizational innovations during the research period [7].

We would like to highlight that innovation process is aimed at implementation and development of acquired and own developments. It requires that certain conditions are formed at the enterprise; the innovation activity is characterized by diversity, which determined the features and specifics of innovation-active enterprise.

The innovation activity is conducted in different directions through innovation project development, their implementation and new product creation. Special condition formation for new technology development and implementation is part of the innovative activity. In this regard numerous indicators are analyzed and assessed to evaluate the innovation activity [5].

In order to assess the development of innovative activities of the organization, in our opinion, one should use indexes of growth indicators (growth rates), which characterize the directions declared for the analysis of innovative activities in dynamics. It is advisable to evaluate the development of innovative activities of an organization with the help of a comprehensive assessment, which is based on the separation and subsequent processing of indicators [9].

Following the principles of a comprehensive analysis, it is proposed to conduct an assessment of the development of innovative activity of an industrial enterprise in stages. The sequence of steps reflects the logic of solving the assigned sub-tasks. The assessment stages are presented in the figure 1.

Selection of forms of enterprise innovation activity, subject to analysis

Determination of indicators, characteristic of directions of enterprise innovation activity, for which the official data of their implementation over the study period are available

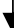

Calculation of growth indices of indicators for each direction of enterprise innovative activity provided for the analysis

\section{$\checkmark$}

Calculation of generalizing integral indicators, characteristic of the level of development of a particular direction of industrial enterprise innovative activity

Determination of the comprehensive indicator, characteristic of the development of industrial enterprise innovative activity as a whole

Fig. 1. Algorithm (stages) for assessment of industrial enterprise innovative activity development 
The first subtask is solved by identifying directions of innovation that are subject to analysis. For an innovatively active enterprise, in our opinion, three directions should be envisaged that reflect the following types of innovative activity:

- Innovative activity related to the creation of conditions for the development of ideas, development and implementation of innovations;

- Innovation activity, including research, development work and experimental development;

- Activities for the implementation of scientific and design developments and innovations.

At the second stage, quantitative indicators are selected that characterize each direction of the organization's innovative activity.
In our opinion, the group of indicators characterizing innovative activities to create conditions for research, development and implementation of innovations should include: the value of fixed assets; participation in targeted programs and state orders; number of workplaces [6]. Assessment of innovation in the second direction should be based on the indicator "results of research and development." The third area of innovation activity of an innovation-active enterprise, which characterizes the implementation of scientific developments, is proposed to be evaluated based on indicators: revenue and value of intangible assets.

The indicators characterizing each of the three areas of innovative activity of industrial enterprises are presented in the table 1 .

TABLE I. INDICATORS CHARACTERIZING THE DIRECTIONS OF INDUSTRIAL ENTERPRISE INNOVATIVE ACTIVITY

\begin{tabular}{|c|c|c|}
\hline \multirow[t]{15}{*}{ Direction } & \multirow{3}{*}{$\frac{\text { Indicators }}{\text { Fixed assets renewal rate }}$} & $\begin{array}{c}\text { Formula } \\
\end{array}$ \\
\hline & & \multirow{2}{*}{ Ifa $=\frac{\text { cost of write }- \text { off fixed assets }}{\text { cost of introduced fixed assets }}$} \\
\hline & & \\
\hline & \multirow{2}{*}{$\begin{array}{l}\text { Graduate School } \\
\text { performance }\end{array}$} & \multirow{2}{*}{ Igr $=\frac{\text { number of employees, successfully completed postgraduate education }}{\text { number of employees, who are currently postgraduate students }}$} \\
\hline & & \\
\hline & \multirow[t]{2}{*}{ Advanced training } & \multirow{2}{*}{ Itr $=\frac{\text { number of employees, completed advanced training }}{\text { total number of employees }}$} \\
\hline & & \\
\hline & \multirow[t]{2}{*}{ Workplaces growth } & \multirow{2}{*}{ Iwp $=\frac{\text { number of jobs for the reporting year }- \text { number of jobs in previous year }}{\text { number of jobs in previous year }}$} \\
\hline & & \\
\hline & $\begin{array}{l}\text { Participation in public } \\
\text { procurement }\end{array}$ & Ipp $=\frac{\text { budget expenses }}{\text { cost of production }}$ \\
\hline & Patents for inventions & Number of patents for inventions \\
\hline & $\begin{array}{l}\text { Utility model patents } \\
\text { Technology patents }\end{array}$ & Number of patents for utility models \\
\hline & Technology patents & Number of technology patents \\
\hline & Citation of scientists & Icsc $=\frac{\text { citation of researchers at RSCI }}{\text { number of researchers }}$ \\
\hline & $\begin{array}{l}\text { Volume of intangible } \\
\text { assets to the volume of } \\
\text { total expenses }\end{array}$ & Iia $=\frac{\text { intangible assets }}{\text { cost of production }}$ \\
\hline & $\begin{array}{l}\text { Innovative products in } \\
\text { total sales }\end{array}$ & Iip $=\underline{\text { revenue from sales of innovative products }}$ \\
\hline & $\begin{array}{l}\text { Level of } \\
\text { commercialization }\end{array}$ & $\begin{array}{l}\text { sales revenue } \\
\text { number of develoments ready for implementation }\end{array}$ \\
\hline & $\begin{array}{l}\text { Number of advanced } \\
\text { technologies introduced }\end{array}$ & Iadt $=\frac{\text { number of advance technologies implemented }}{\text { total number of advance technologies }}$ \\
\hline & $\begin{array}{l}\text { Number of implemented } \\
\text { innovative projects }\end{array}$ & Iiip $=\frac{\text { number of implemented innovative projects }}{\text { total number of innovative projects }}$ \\
\hline & $\begin{array}{l}\text { Guaranteed sales through } \\
\text { government orders }\end{array}$ & Isgo $=\frac{\text { sales revenue from the state order products }}{\text { sales revenue }}$ \\
\hline
\end{tabular}

At the third stage, the indices of growth of indicators provided for the analysis are calculated for each direction of innovation activity of the innovation-active industrial organization.

This index is defined as the ratio of the value of the indicator of the next year to the value of the base (previous) year.

At the fourth stage, generalizing integral indicators are calculated for the given areas of innovative activity of an industrial enterprise.

Generalizing integrated indicators for the areas of innovative activity of the organization will be calculated by the formula (1):

$$
J_{\text {ia }}=\sqrt[n]{\prod_{n=1}^{n} K_{i}},
$$

where $K_{i}$ - individual indicators characterizing a group of conditions;

$n-$ a number of individual indicators;

$J_{\text {ia }}$ - generalizing indicator, characterizing the level of development of each direction of the organization's innovative activit. 
The fifth subtask is the calculation of the comprehensive indicator characterizing the development of innovative activity (all 3 directions) of an industrial enterprise.

Using expert methods, we establish the weighting factors of each of the areas of innovation and find a comprehensive indicator that determines the overall level of development of the innovation activity of the organization as a whole. To do this, we can use the following formula (2):

$$
A_{\text {ia }}=\sum_{j=1}^{n} J_{\mathrm{ia}(\mathrm{j})} * B_{j}
$$

where $A_{\text {ia }}$ - indicator of a comprehensive assessment of the development of innovative activities of the organization;

$B_{j}$ - weight value of a general indicator of the development of the direction of innovative activity of the organization.

The value of the calculated indicator characterizes the level of development of innovative activity of an industrial enterprise for the year. Analysis of the dynamics of generalized indicators of the level of development of innovative activities of the organization allows drawing the conclusions on the trends of innovative development of the enterprise.

This technique is applicable to assess the development of innovative activities of competing enterprises, as available data from the financial statements of the organization are used. It is advisable to use this methodological approach to government bodies to assess the development and forecast trends of innovative development of enterprises in the region.

Based on the results, it is advisable to build a threedimensional model to determine the priority areas for the development of innovative activities of the organization, presented in the figure 2 .

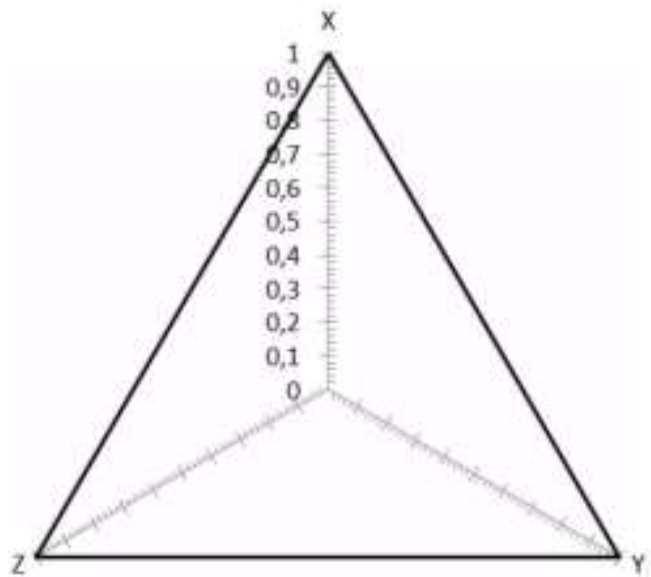

$\mathrm{X}$ - creation of conditions for research, development and implementation of innovations

$\mathrm{Y}-$ activities including research, design

$\mathrm{Z}$ - research and development implementation activities

Fig. 2. Benchmarks of development in the areas of innovation of an industrial enterprise
The axes of $\mathrm{X}, \mathrm{Y}, \mathrm{Z}$ are the fields of values of the development of innovative activities of the organization:

- $\mathrm{X}$ is a general indicator of the level of development of innovative activities related to the creation of conditions for the development of ideas, development work and implementation of innovations;

- $\mathrm{Y}$ is a general indicator of the level of development of innovative activity, which includes directly research, experimental design work and experimental development;

- $\mathrm{Z}$ is a general indicator of the level of development of activities for the implementation of scientific and design developments and innovations.

A continuous line on the axes $\mathrm{X}, \mathrm{Y}, \mathrm{Z}$ shows the values equal to 1 . It characterizes the starting point in the development of innovative activity of an industrial enterprise in each direction.

In order to calculate the overall complex indicator characterizing the level of development of innovative activity of an industrial organization, we assign a significance coefficient to each of the directions, presented in table 2.

TABLE II. COEFFICIENT OF SIGNIFICANCE OF INDICATORS OF AREAS OF INNOVATION

\begin{tabular}{|l|l|}
\hline \multicolumn{1}{|c|}{ Directions of innovation activities } & $\begin{array}{c}\text { Significance } \\
\text { coefficient }\end{array}$ \\
\hline $\begin{array}{c}\text { 1. Creation of conditions for the development of ideas, } \\
\text { development and implementation of innovations }\end{array}$ & 0,3 \\
\hline $\begin{array}{c}\text { 2. Innovative activities, including research, development and } \\
\text { experimental development }\end{array}$ & 0,4 \\
\hline $\begin{array}{c}\text { 3. Activities for the implementation of scientific and design } \\
\text { developments and innovations }\end{array}$ & 0,3 \\
\hline
\end{tabular}

To define the level of development of innovative activity of an industrial enterprise departmental managers should calculate the relevant indicators (the intensity of renewal of fixed assets, workplaces growth, advanced training, the amount of intangible assets to the total volume of expenses, the number of patents for inventions, technologies, innovative products in total sales revenue, the number of implemented advanced technologies, etc.), compare these indicators with the data from previous periods, evaluate the effectiveness of implemented innovative projects and their impact on the industrial and economic activities of an industrial enterprise and simultaneously identify ways to improve these indicators [10].

\section{RESULTS}

In our opinion, when analyzing the development of innovative activities of industrial enterprises, it is necessary to use a system of indicators that makes it possible to assess the quality parameters of enterprise performance after applying innovations and accelerating their innovative activities.

In this context, the use of indicators which can help to evaluate the industrial enterprise production efficiency as a result of its innovation activity is of great importance. Such a system of indicators will demonstrate the level and dynamics of production efficiency, the degree to which production 
resources are used, it will direct enterprise management towards dynamic efficiency growth, which manifests itself in profit or sales increase [11].

The advantage of using these indicators is that management of industrial enterprises at different levels has data for their calculation. The calculation of these indicators does not set any difficulty and can be carried out periodically. Thus, the information obtained with these indicators makes an important basis to monitor the effectiveness of implemented innovative measures in industrial enterprise activities, that is, it can significantly expand the data base to make optimal management decisions [8].

Based on the considered methodology, we will conduct a comprehensive assessment of the innovative activity of industrial enterprises of Concern Constellation JSC for the period 2012-2017 in order to determine the level of innovation development.
The comprehensive assessment will be conducted in 3 directions of innovation activity: creating conditions for development and implementation of innovations; research, development and experimental development; activities for the implementation of scientific and design developments and innovations, as present in table 3 .

Based on the assessment of the level of development of innovative activity of enterprises belonging to the Concern Constellation JSC (Figure 2), we can conclude that in order to achieve the most effective development of innovative activity, in our opinion, it is advisable to introduce an interaction mechanism based on integration. This mechanism will allow project management in the implementation of innovative developments and cooperation of scientific and industrial enterprises when conducting research, it will also allow joint production, including $\mathrm{R} \& \mathrm{D}$.

TABLE III. GROWTH INDICES OF INDICATORS OF INNOVATIVE ACTIVITY AND GENERALIZING INTEGRATED INDICATORS CHARACTERIZING THE LEVEL OF DEVELOPMENT OF INNOVATIVE ACTIVITY OF A COMPLEX OF ENTERPRISES INCLUDED IN JSC CONCERN CONSTELLATION FOR 2012-2017

\begin{tabular}{|c|c|c|c|c|c|c|}
\hline Directions, indicators & 2012 & 2013 & 2014 & 2015 & 2016 & 2017 \\
\hline \multicolumn{7}{|c|}{$\begin{array}{l}\text { Direction 1. Indicators, characterizing innovative activity related to the creation of conditions for the development of ideas, development and implementation of } \\
\text { innovations }\end{array}$} \\
\hline Fixed assets renewal rate & 1,28 & 1,12 & 1,21 & 1,06 & 1,18 & 1,27 \\
\hline Graduate School performance & 0,93 & 0,97 & 0,74 & 0,89 & 0,91 & 1,02 \\
\hline Training & 1,12 & 1,20 & 1,13 & 1,01 & 1,07 & 1,12 \\
\hline Workplaces growth & 1,11 & 0,89 & 1,09 & 1,04 & 1,02 & 1,01 \\
\hline Participation in public procurement & 0,83 & 0,97 & 0,85 & 0,89 & 0,99 & 1,09 \\
\hline $\begin{array}{l}\text { Integral indicator } \mathrm{Ij}(1) \\
\mathrm{Ij}(1)=5 \sqrt{i}_{1} *_{\mathrm{i}} 2 * \mathrm{i} 3 * \mathrm{i} 4 * \mathrm{i} 5\end{array}$ & 1,04 & 1,03 & 0,99 & 0,98 & 1,03 & 1,05 \\
\hline \multicolumn{7}{|c|}{ Direction 2. Indicators, characterizing innovative activity including research, development work and experimental development } \\
\hline Patents for inventions & 1,12 & 1,10 & 1,15 & 0,96 & 0,93 & 1,21 \\
\hline Utility model patents & 1,05 & 0,93 & 1,15 & 1,05 & 1,01 & 1,09 \\
\hline Technology patents & 0,72 & 0,85 & 0,82 & 0,94 & 0,94 & 0,94 \\
\hline Citation of scientists & 1,15 & 1,01 & 1,15 & 1,03 & 0,94 & 1,04 \\
\hline $\begin{array}{l}\text { Volume of intangible assets to the volume of } \\
\text { total expenses }\end{array}$ & 1,10 & 1,01 & 1,00 & 0,99 & 1,07 & 1,08 \\
\hline $\begin{array}{l}\text { Integral indicator } \mathrm{Ij}(2) \\
\mathrm{Ij}(2)=5 \sqrt{i} 1 *_{\mathrm{i}} 2 * \mathrm{i} 3 * \mathrm{i} 4 * \mathrm{i} 5\end{array}$ & 1,01 & 0,98 & 1,05 & 0,99 & 0,98 & 1,07 \\
\hline \multicolumn{7}{|c|}{ Direction 3 - Indicators, characterizing activities for the implementation of scientific and design developments and innovations } \\
\hline Innovative products in total sales & 0,87 & 0,83 & 0,94 & 1,15 & 1,06 & 1,17 \\
\hline Level of commercialization & 0,99 & 0,98 & 0,89 & 1,07 & 0,90 & 1,11 \\
\hline Number of advanced technologies introduced & 0,87 & 0,87 & 0,98 & 0,98 & 1,09 & 1,16 \\
\hline Number of implemented innovative projects & 0,95 & 0,93 & 1,13 & 1,06 & 1,06 & 1,14 \\
\hline Guaranteed sales through government orders & 0,99 & 0,69 & 0,78 & 0,79 & 1,05 & 1,12 \\
\hline $\begin{array}{l}\text { Integral indicator } \mathrm{Ij}(3) \\
\mathrm{Ij}(3)=5 \sqrt{\mathrm{i} 1} *_{\mathrm{i} 2} * \mathrm{i} 3 * \mathrm{i} 4 * \mathrm{i} 5\end{array}$ & 0,93 & 0,85 & 0,99 & 1,00 & 1,03 & 1,14 \\
\hline
\end{tabular}

\section{CONCLUSION}

The solution to the problem of innovation development is possible when large and small enterprises being part of the same industry are combined into an integrated structure thus joining their activities. Such a structure should provide each enterprise with priorities and certain areas for the development of innovative activities in accordance with their competitive advantages [12] and then distribute projects for implementation, rationally using the resources possessed by the integrated structure, and taking into account the potential of its actors. This will bring a synergistic effect and increase the efficiency of each enterprise and improve the competitiveness of the company as a whole
Such an approach can help attract federal and regional budget funds to the activities of industrial enterprises, to include them in various programs for the development of an innovative economy and provide them with state support. The effective development of innovation will allow enterprises to become the locomotive of the Russian economy.

In our opinion, the development of innovative activity of industrial enterprises depends on formation of integrated structure, with aim to increase financial performance, conduct technological modernization, manufacture and sell competitive products, and minimize business risks. In addition, the integration structure will create an information base to accumulate defense orders from Russia and orders from other countries of the world community. 
Thus, the comprehensive assessment of innovative activity made it possible to calculate the level of innovative development of enterprises of Concern Constellation JSC and identify trends in the development of various areas of innovative activity, which, in turn, allows identifying problems of innovative development of enterprises and determine ways to solve them.

\section{References}

[1] V.P. Voronin, I.M. Podmolodina, "Theoretical issues of economic growth and competitiveness of Russia", Vest. VGTA, vol. 10, pp. 171-178, 2005.

[2] G.Y. Goldshtein, Strategic innovative management: manual. Taganrog: TRTU, 2004, $225 \mathrm{p}$

[3] P.N. Zavlin, A.V. Vasiliev, Innovation efficiency assessment. St. Petersburg: Publ. House "Business-Press", 2003, 216 p.

[4] S.G. Zelenskaya, Y.A. Pertsev, "New technology economy: financial aspects of regional innovative development", Energy, vol. 1-2, no. 82-83, pp. 107-131, 2012.

[5] N.S. Krasnokutskaya, "Enterprise potential assessment. Methodological approach", Sci. J. Acad. Rev., vol. 1, no. 32, pp. 67-72, 2010. Dnepropetrovsk: Dnepropetrovsk univer. of econ. and law.

[6] O.O. Lukina, V.V. Dudchak, "Generalized indicator and classification structures of the capital of the industrial enterprises", Proc. of the Voronezh State Univer. of Engineer. Technol., vol. 80, no. 3, pp. 423-428, 2018. Retrieved from: https://doi.org/10.20914/2310-1202-2018-3-423-428.
[7] T.T. Makarevitch, A.S. Gavriluk, T.O. Petrushka, "Integral impact on enterprise innovative activity. Methodological approaches", Vest. of Lvov national univer., vol. 594, p. 269, 2007. Lvov: Publ. house of National univer. "Ivov politechnics".

[8] A.P. Urubkov, I.F. Fedotov, Methods and models for managerial decision optimization. Moscow: Delo, 2009, 240 p.

[9] N.A. Serebryakova, A.V. Petrikov, "The principles of design and the organization of functioning of innovative infrastructures in the conditions of the Industry 4.0.", Proc. of the Voronezh State Univer. of Engineer. Technol., vol. 80, no. 4, pp. 384-387, 2018. Retrieved from: https://doi.org/10.20914/2310-1202-2018-4-384-387.

[10] B.S. Blanchard, W.J. Fabrycky, Systems engineering and analysis, 4-th ed. Prentice Hall, 2016.

[11] N.A. Serebryakova, T.I. Ovchinnikova, I.N. Bulgakova, S.V. Sviridova, T.O. Tolstykh, "Innovational methods of development of intellectual labor for economy's security", Europ. Res. Studies J., vol. 20, no. 3, pp. 556-569.

[12] N.A. Serebryakova, T.O. Tolstykh, N.V. Dorokhova, E. Solomatina, M.I. Isaenko, "The effectiveness of using the innovational potential of a socio-economic system in Russia", Int. J. of Trade and Global Markets, 2018.

[13] T.O. Tolstykh, N.N. Kretova, A.A. Trushevskaya, E.S. Dedova, M.S. Lutsenko, "Problems and Prospects for Implementing Interdimensional and Inter-industry Projects in Digital Economy", Advan. in Intellig. Syst. and Comput., vol. 622, pp. 485-493, 2018. 